\title{
ЕФЕКТИВНІ СКЛАДОВІ ЯКІСНОЇ ОЦІНКИ КЛІНІЧНОГО МИСЛЕННЯ СТУДЕНТІВ У ПРОЦЕСІ ВИВЧЕННЯ ВНУТРІШНЬОЇ МЕДИЦИНИ
}

\author{
М. О. Вацеба \\ ДВНЗ “Івано-Франківський національний медичний університет”

\section{EFFECTIVE COMPONENTS OF EVALUATION OF CLINICAL THINKING OF THE STUDENTS IN TNE INTERNAL MEDICINE STUDYING}

M. O. Vatseba

\author{
Ivano-Frankivsk National Medical University
}

\begin{abstract}
Статтю присвячено проблемі використання клінічного мислення як ефективного методу навчання студентів. Загальним завданням вищої медичної школи є підготовка практичного лікаря, здатного до діагностики, лікування та профілактики захворювання. Курс клінічного мислення - це метод навчання професійної діяльності за допомогою ії моделювання, близького до реальних умов, з обов'язковим динамічним розвитком розв'язуваної ситуації, завдання або проблеми в чіткій відповідності наступних подій з характером рішень та дій. Розглядається проблема доцільності використання даного методу під час навчання студентів-медиків.
\end{abstract}

The article is devoted to the use of clinical thinking as an effective teaching method in medical education. The overall objective of higher medical education is to prepare practitioners, able to diagnostics, treatment and prevention of disease. The course of clinical thinking - is a method of teaching of professional activities through its modeling close to the real conditions of compulsory dynamic development of the situation, task or problem in strict accordance with character of the following events decisions and action. The problems of interactivity and usefulness of this method in the training of medical students are considered.

Вступ. Клінічне мислення в широкому сенсі не може бути зведене до мислення в звичайному для логіки розумінні. Це не тільки рішення складних логічних задач, але і здатність до спостережливості, встановлення психологічного контакту, довірчих відносин з хворим, розвиток інтуїції та "відтворення уяви”, що дозволяє уявити патологічний процес в його цілісності $[1,5]$. Під клінічним мисленням розуміють можливість студента-медика виділяти головне, узагальнювати, визначати розбіжності, синтезувати крихти інформації, які він отримав, проводячи обстеження хворого, вислуховуючи його скарги, здійснюючи лабораторне та інструментальне дослідження з метою швидкого та точного встановлення діагнозу [3, 4].

Основна частина. У формуванні клінічного мислення у студентів велику роль відіграє використання в процесі навчання ігрових імітаційних методів - ситуаційних завдань з вирішенням прак-

(c) М. О. Вацеба тичних питань тактики, лікувально-діагностичних, експертних, профілактичних та інших аспектів. Клінічного мислення не можна навчитися за допомогою підручників та посібників, як би добре вони не були складені. Для цього необхідна практика під керівництвом досвідченого викладача $[2,4,5]$.

Клінічне мислення $є$ необхідною складовою професійних навичок у роботі практичного лікаря. Процес оволодіння цим навиком $є$ довготривалим та потребує всебічного та комплексного підходу. Лікар завжди потребує обережних, ретельних роздумів, звернення до письмових джерел та думки колег.

Основними навчальними цілями при проведенні заняття з оцінки клінічного мислення у внутрішній медицині, перш за все, є стимулювання розвитку клінічного мислення студента, яке буде використовуватися у їх майбутній професійній діяльності. Також невід'ємною навчальною ціллю є скорочення часу для отримання професійного досвіду та мотивація студентів до самостійної роботи. Як результат належного освоєння даного курсу одер- 
жання можливості студентам отримати різнобічне уявлення про професійну діяльність.

На першому занятті курсу з клінічного мислення у внутрішній медицині визначаються студенти, котрі виконуватимуть роль так званого “викладача”. “Викладач” готує презентацію клінічного випадку після курації хворого в стаціонарі, вивчення історії хвороби та консультацій з викладачем. У групі студентів визначаються “спеціалісти з інструментальних методів та лабораторних методів дослідження”. “Викладач” презентує клінічний випадок та веде його розбір згідно з основними етапами, формує клінічне мислення. “Викладач” ставить такі питання студентам: 1. Яка інформація потрібна про симптоми у даного хворого? 2. Яку інформацію ви хочете отримати про результати об’єктивного обстеження даного хворого? 3. Які можливі причини розвитку гострого болю в грудях? Проводиться аналіз, аргументація та дискусія. Наступним етапом студентами проводиться заповнення таблиці ймовірності патології, яка може викликати даний синдром. “Викладач” демонструє результати об’єктивного обстеження. Після демонстрації результатів об'єктивного обстеження “викладач” відповідає на всі додаткові запитання, які виникли у студентів, щодо об’єктивного обстеження даного хворого. Викладач надає бланки для заповнення таблиці “Диференційна діагностика симптомів при різних захворюваннях”. Студентами проводиться формування переліку додаткових методів дослідження. Обговорюється їх доцільність. Після цього “викладач” почергово демонструє результати обстеження. “Спеціалісти” з діагностики інтерпретують результати дослідження. “Спеціалісти” та інші студенти беруть активну участь у всіх етапах розбору клінічного випадку. Отримавши результати додаткових обстежень, студенти виставляють клінічний діагноз та формулюють листок лікарських призначень. Один із студентів групи коротко підсумовує весь клінічний випадок у хронологічному порядку. Підсумок заняття з клінічного мислення проводиться шляхом активної дискусії за участю викладача, професора. Заняття проводиться в клініці або в навчально-практичному центрі кафедри. Використовуються мультимедійний проектор, смарт-дошка, телевізор, апаратура для проведення додаткових методів інструментального та лабораторного дослідження, манекен. За допомогою даного методу у студентів розвивається клінічне мислення, а дані навики неодмінно будуть використані у подальшій професійній діяльності.
Загальним завданням вищої медичної школи є підготовка практичного лікаря, здатного до діагностики, до лікування та профілактики захворювання. Курс клінічного мислення - це метод навчання професійної діяльності за допомогою її моделювання, близького до реальних умов, з обов'язковим розгалуженим динамічним розвитком розв'язуваної ситуації, завдання або проблеми в чіткій відповідності наступних подій з характером рішень та дій.

Сучасний лікар повинен володіти гнучким, пластичним мисленням, що виявляється в швидкості перетворення, зміни способу, тактики лікування, діагностичних висновків у відповідності зі змінами об’єктивної ситуації (зміни перебігу хвороби або стану хворого, атипової картини хвороби і т. д.). Це передбачає виділення істотних сторін таких змін, можливість відходу від звичних дій, від стереотипу і знаходження нових шляхів вирішення, комбінації елементів минулого досвіду.

Таким чином, справжня клінічна робота є завжди творчою справою. Основна мета професійного навчання лікаря - це формування творчого лікарського мислення як основи професійної творчої діяльності. При лікуванні необхідно розкрити сутність такого складного процесу, як захворювання людини, а це є професійним мисленням. Потреба в такому мисленні виникає з самої клінічної практики.

Клінічне мислення дозволяє оцінювати стан хворого як цілісного організму, з урахуванням всіх його особливостей, розглядає хворобу як процес, 3'ясовуючи фактори, що призводять до її розвитку, iї подальшу еволюцію з ускладненнями та супутніми захворюваннями. Такий підхід дозволяє підібрати правильну схему лікування. Облік принципів діалектики, з'ясування причинно-наслідкових зв’язків між процесами, що відбуваються в організмі, використання при вирішенні питань основних принципів логіки дозволяють мисленню вийти на якісно новий рівень розвитку.

Висновки: 1. Модернізація медичної освіти в Україні на сьогодні є необхідною умовою формування студента-медика. Шляхами досягнення такого результату є запровадження нових методик навчання на основі клінічного мислення студентамедика. Завдяки такому підходу до модернізації медичної освіти вдасться підвищити якість підготовки майбутніх лікарів.

2. Організація цілісного адаптивно-динамічного процесу навчання студентів-медиків, розвиток у них особистісних структур включає різні форми взаємодії зі студентами, спілкування студентів 
між собою під час навчальних занять, враховуючи їх приховані потенційні можливості розвитку всіх компонентів майбутньої професійної компетентності.

\section{Список літератури}

1. Захарченко Т. Роль наочності у процесі викладання професійно орієнтованих дисциплін / Т. Захарченко // Вища школа. - 2013. - № 12. - С. 30-38.

2. Лемешев А. Ф. Клиническое мышление. Врачебная логика как основа методологии диагноза : учеб.-метод. пособие / А. Ф. Лемешев. - Мн. : БГМУ, 2006. - 74 с.

3. Ляшук П. М. Клініка - вища школа лікарської майстерності / П. М. Ляшук, В. П. Пішак // Буковинський медичний вісник. - 2007. - Т. 11, № 1. - С. 151-153.
3. Формування клінічного мислення необхідно розглядати як органічну частину становлення особистості майбутнього лікаря.

4. Семидоцкая Ж. Д. Клиническое мышление и XXI век / Ж. Д. Семидоцкая, И. А. Чернякова, И. С. Кармазина // Східноєвропейський журнал внутрішньої та сімейної медицини. - 2016. - № 1.- С. 100-103.

5. Тетенев Ф. Б. Формирование и развитие клинического мышления - важнейшая задача медицинского образования / Ф. Б. Тетенев, Т. Н. Бодрова, О.В.Калинина // Успехи современного естествознания. - 2008. - № 34. C. 63-65. 